\title{
Analisis Konsep Perbelanjaan Perkahwinan Rasulullah SAW
}

\author{
Syh Noorul Madihah Syed Husin \\ Universiti Sultan Zainal Abidin, madihah@unisza.edu.my \\ Raihanah Azahari \\ Universiti Malaya, raihan@um.edu.my \\ Asmak Ab Rahman \\ Universiti Malaya, asmak.unimalaya@gmail.com
}

\begin{abstract}
Abstrak
Perbelanjaan perkahwinan merupakan peruntukan harta yang perlu dibelanjakan sebagai persiapan untuk mendirikan rumah tangga. Ia adalah satu keperluan kepada pasangan yang akan berkahwin. Rasulullah SAW pernah membelanjakan harta untuk pembayaran mas kahwin dan penganjuran walimah sempena perkahwinan baginda. Mutakhir ini, perbelanjaan perkahwinan masyarakat tempatan dilihat semakin tinggi. Trend sambutan perkahwinan secara besar-besaran dengan pelbagai adat dan kelengkapan semasa memerlukan kepada puluhan ribu ringgit. Ia bukan sahaja semakin membebankan pasangan yang akan berkahwin, malah boleh membawa kepada budaya berhutang dan berkahwin di lewat usia. Kekurangan penerokaan terhadap corak dan gaya perbelanjaan perkahwinan Rasulullah SAW semakin meruncingkan isu ini. Masyarakat seolah-olah hanya meneruskan trend tersebut tanpa didedahkan dengan panduan dalam menguruskan perbelanjaan perkahwinan mereka. Justeru itu, artikel ini bertujuan untuk mengkaji corak perbelanjaan perkahwinan Rasulullah SAW bagi mengemukakan konsep perbelanjaan perkahwinan yang telah dibawa oleh baginda. Sebagai sebuah kajian kualitatif, kajian ini akan menggunakan kaedah analisis dokumen dengan menelusuri dan meneliti peristiwa-peristiwa berkaitan corak perbelanjaan perkahwinan daripada sumber-sumber muktamad. Hasil analisis, kajian mendapati terdapat empat konsep perbelanjaan perkahwinan yang telah dipamerkan oleh Rasulullah SAW iaitu i) perbelanjaan bermanfaat, ii) perbelanjaan mengikut tahap kemampuan, iii) perbelanjaan secara sederhana dan iv) perbelanjaan secara kerjasama. Konsep tersebut sewajarnya dijadikan panduan dan seterusnya diterapkan oleh masyarakat dalam pengurusan perbelanjaan perkahwinan mereka mengikut kesesuaian semasa.
\end{abstract}

Kata kunci: perbelanjaan perkahwinan, konsep perbelanjaan perkahwinan, perkahwinan Rasulullah SAW 


\title{
An Analysis of the Concept of Marriage Expenses of the Prophet p.b.u.h.
}

\begin{abstract}
Marriage expenses are an allocation of money spent in preparation for marriage. It is a necessity to married-to-be couples. Rasulullah p.b.u.h. himself gave dowry and organized walimah on his marriage. To date, the marriage expenses of local communities are seen to be getting higher. It is already becoming a trend of throw a luxurious wedding celebration with a variety of traditional and current equipment which amounts to thousands of dollars. It is not burden-some for couples who are getting married, but instead can lead to a culture of debt and late marriages. In addition to it, there is a lack of research on the patterns and styles of marriage expenses practiced by Rasulullah p.b.u.h. Society seems to only continue the trend without being exposed to the right guidelines in managing their marriage expenses. Therefore, this article aims to review the spending patterns of marriage Prophet for submitting concept of marriage expenses that have been practiced by him. As a qualitative study, this study will use a method of document analysis to explore and examine the events of the wedding expenditure pattern from various sources. The study found that there are four wedding expenses concept that has been exhibited by the Prophet Muhammad p.b.u.h., namely i) the worthwhile expenditure, ii) expenditures by level of ability, iii) moderate expenditure and iv) collaborative expenditure. The concept should be the guide and subsequently adopted by the community in the management of their marriage expenses according to current requirements.
\end{abstract}

Keywords: marriage expenses, concept of marriage expenses, Rasulullah's p.b.u.h. marriage

\section{Pendahuluan}

Rasulullah SAW merupakan contoh tauladan yang lengkap dalam semua aspek kehidupan berkeluarga, termasuklah dalam hal berkaitan perbelanjaan bagi persediaan perkahwinan. Urusan perkahwinan tidak pernah digambarkan sebagai satu perkara yang membebankan oleh Rasulullah SAW, bahkan baginda amat menganjurkan perkahwinan di usia muda setelah berkemampuan untuk melaksanakannya. ${ }^{1}$ Meskipun perkahwinan memerlukan

1 Maksud hadis: "Wahai para pemuda, barang siapa di antara kalian yang mampu bernikah, maka bernikahlah..." Hadith riwayat al-Bukhārī, Kitāb alNikāḥ, Bāb Man Istațā‘ minkum al-Bā'ah fa al-Yatazawwaj fa innahu Aghaḍḍu li al-Bașar wa Aḥ̦an li al-Farj. Wa Ḥal Yatazawwaj Man lā 'Arab 
pelbagai persediaan termasuk dari sudut kewangan, namun melalui sirah baginda, Rasulullah SAW sentiasa mengemukakan jalan penyelesaian ke arah memudahkan urusan tersebut. Konsep memudahkan urusan perbelanjaan perkahwinan terserlah pada anjuran penetapan kadar mas kahwin dan pengendalian walimah oleh baginda. ${ }^{2}$

Walaupun pada dasarnya ajaran Rasulullah SAW adalah mempermudahkan urusan perkahwinan tanpa melibatkan perbelanjaan yang besar, namun intipati ajaran baginda ini tidak diikuti dengan sepenuhnya oleh masyarakat pada masa kini. Ia rentetan daripada menularnya trend perbelanjaan perkahwinan yang tinggi dalam kalangan masyarakat setempat. Perubahan sosial dari aspek persiapan dan sambutan perkahwinan oleh masyarakat telah menyumbang kepada perbelanjaan yang tinggi. Lokasi majlis telah berpindah dari halaman rumah ke dewandewan tertentu dan hotel-hotel mewah, manakala menu yang disediakan pula telah dipakejkan oleh pihak penyaji, dewan mahu pun hotel. ${ }^{3}$ Masyarakat turut didedah dengan pelbagai kemudahan untuk menjayakan sambutan perkahwinan termasuklah penawaran pakej perkahwinan oleh perunding-perunding perkahwinan. Dari aspek perbelanjaan yang melibatkan aturan adat masyarakat Melayu pula, pasangan tidak terlepas dari pelbagai elemen perbelanjaan adat seperti wang hantaran, penyediaan barang kemas sempena pertunangan dan perkahwinan, serta pelbagai lagi amalan adat yang boleh menyumbang kepada perbelanjaan. Perbelanjaan untuk wang hantaran umpamanya, telah mencecah ribuan ringgit. Menurut kajian yang dilakukan kepada sekumpulan responden di utara semenanjung, majoriti responden telah menyatakan kadar yang paling munasabah bagi wang hantaran

lahu fĩ al-Nikāḥ, no. 5065. Lihat Abū 'Abd Allāh Muhammad bin Ismā’̄̄l alBukhārī, "Ṣaḥīh al-Bukhārī”, dalam Mawsū'at al-Hadīth al-Sharīf al-Kutub al-Sittah, ed. Șālị̣ bin 'Abd al-'Azīz al-Shaykh (Riyādh: Dār al-Salām, 2000), 438.

2 Syh Noorul Madihah Syed Husin, Raihanah Azahari dan Asmak Ab. Rahman, "Konsep al-Taysir dalam Perbelanjaan Perkahwinan Islam", Jurnal Syariah 22, no.3 (September - Disember 2014), 337.

3 Fatimah Abdullah, "Dari Halaman Rumah ke Dewan Merak Kayangan", SARI Jurnal Alam dan Tamadun Melayu 27, no.1 (Jun-Disember 2009), 101. 
pada masa sekarang adalah di antara RM5000 hingga RM8000. ${ }^{4}$ Situasi yang dipaparkan ini telah menyumbang kepada peningkatan perbelanjaan perkahwinan dalam kalangan masyarakat Islam. Jika sekitar tahun 1980-an, sebuah perkahwinan pasangan Melayu muslim pada kebiasaannya menelan belanja sekitar RM 4,000 hingga Rm 6,000, ${ }^{5}$ namun kini secara puratanya ia telah mencecah puluhan ribu ringgit jika mengikut adat istiadat Melayu dan keinginan pihak keluarga. ${ }^{6}$

Fenomena perbelanjaan sebegini tinggi dilihat boleh mendatangkan pelbagai implikasi negatif kepada masyarakat muslim, khususnya pasangan yang mendirikan rumah tangga. Antara isu yang membimbangkan kebelakangan ini adalah bebanan hutang yang perlu ditanggung oleh pasangan yang baharu berkahwin. Secara purata, majlis perkahwinan masyarakat Melayu Islam kini boleh mencecah puluhan ribu ringgit ${ }^{7}$ Ia merupakan satu jumlah yang agak menyukarkan bagi muda-mudi untuk menyediakannya. Menurut Ketua Pegawai Eksekutif Agensi Kaunseling dan Pengurusan Kredit (AKPK) Koid Swee Lian, antara punca utama mereka yang dibelenggu hutang adalah melibatkan pinjaman bagi pengurusan perbelanjaan perkahwinan. Faktor kos untuk persiapan perkahwinan, wang hantaran dan hadiah hantaran yang tinggi telah menyebabkan bakal pengantin terpaksa berhutang melalui pinjaman peribadi dan lain-lain bentuk pinjaman. $^{8} \quad$ Perbelanjaan perkahwinan yang tinggi turut menyukarkan urusan perkahwinan kepada kaum muda. Penetapan kadar wang hantaran yang tinggi menyebabkan pasangan lelaki terpaksa berfikir beberapa kali sebelum membuat keputusan untuk berkahwin dan mengambil masa yang lama bagi menyimpan wang

4 Raihanah Azahari, Khairun Najmi Saripudin dan Raihana Abd Wahab, "Hubungan di antara Faktor Demografi dengan Penentuan Kadar Hantaran: Kajian di Perlis, Kedah, Pulau-Pinang dan Perak”, Jurnal Fiqh 6 (2009), 123.

5 Persatuan Pengguna Pulau Pinang, Anda dan Wang Anda: Bagaimana Menyimpan \& Berbelanja dengan Bijak (Pulau-Pinang: Persatuan Pengguna Pulau Pinang, 1987), 88.

6 Fatimah Abdullah, "Dari Halaman Rumah ke Dewan Merak Kayangan", 106.

7 Fatimah Abdullah, "Dari Halaman Rumah ke Dewan Merak Kayangan”, 106.

8 “Pengantin Dibelenggu Hutang", Laman AKPK, 11 Disember 2012, dicapai 10 Mac 2013, http://www.akpk.org.my/happenings/news/pressrelease/id/486/pengantin-dibelenggu-hutang. 
sebelum boleh mendirikan rumah tangga. ${ }^{9}$ Kaum belia semakin merasa khuatir untuk berkahwin pada usia muda. ${ }^{10}$ Keadaan ini seterusnya boleh memberi impak kepada usia pertama perkahwinan. Merujuk kepada hasil Kajian Penduduk dan Keluarga Malaysia oleh Lembaga Penduduk dan Pembangunan Keluarga Negara (LPPKN) pada tahun 2004, umur min perkahwinan pertama rakyat Melayu semenanjung Malaysia bagi golongan lelaki adalah 28.8, manakala bagi perempuan pula adalah 24.1 tahun. ${ }^{11}$ Bagi kaum lelaki, statistik ini adalah satu peningkatan jika dibandingkan dengan umur min perkahwinan pertama pada tahun 2000, di mana umur minnya adalah 27.9. ${ }^{12}$ Peningkatan ini mungkin ada kaitannya dengan masalah bebanan perbelanjaan perkahwinan yang tinggi.

Realitinya, Rasulullah SAW telah terlibat secara langsung dalam pengurusan perbelanjaan perkahwinan melalui pembayaran mas kahwin dan penganjuran walimat al-urs sempena perkahwinan baginda. Apa yang pernah dipapar oleh Rasulullah SAW dalam menguruskan perbelanjaan perkahwinan, perlu ditonjolkan sebagai satu konsep umum bagi dijadikan panduan kepada mereka yang akan mendirikan rumah tangga. Tanpa panduan, masyarakat akan sentiasa terikut-ikut dengan trend semasa dan berbangga dengan perbelanjaan perkahwinan yang tinggi. Justeru, artikel ini akan membincangkan dua elemen utama perbelanjaan perkahwinan yang pernah dibelanjakan oleh baginda, iaitu bayaran mas kahwin dan penganjuran walimat al-urs. Ia bertujuan bagi mengemukakan konsep perbelanjaan perkahwinan yang telah diketengahkan oleh baginda. Menerusi kaedah analisis dokumen, dokumen-dokumen berasaskan sumber primer iaitu hadis-hadis yang memperihalkan tentang perbelanjaan perkahwinan Rasulullah SAW dan sumber skunder yang terdiri

9 Haslina Hassan dan Ann Wan Seng, Wanita dan Perkahwinan (Kuala Lumpur: Dewan Bahasa dan Pustaka, 1995), 63.

10 Fatimah Abdullah, "Dari Halaman Rumah ke Dewan Merak Kayangan", 106.

11 Kementerian Pembangunan Wanita, Keluarga dan Masyarakat, dicapai 13 Mac 2013, http://www.kpwkm.gov.my/documents/10156/95f9e1b3-24bb4cce-af4b-da9bf8317f2e.

12 Jabatan Perangkaan Malaysia, dicapai 13 Mac 2013, http://www.statistics.gov.my/portal/download_Labour/files?BPTMS/PST-

Siri6.pdf. 
daripada karya-karya fiqh dan hadis, beberapa konsep perbelanjaan perkahwinan akan dikenalpasti dan dianalisis secara diskriptif.

\section{Pemberian Mas Kahwin oleh Rasulullah SAW}

Sirah perkahwinan Rasulullah SAW setelah dilantik menjadi Rasul telah memaparkan beberapa bentuk pemberian mas kahwin oleh baginda kepada isteri-isteri baginda. Secara umumnya baginda diriwayatkan tidak pernah membayar mas kahwin kepada isterinya melebihi dari 500 dirham. Abū Salamah bin 'Abd alRaḥman telah meriwayatkan:

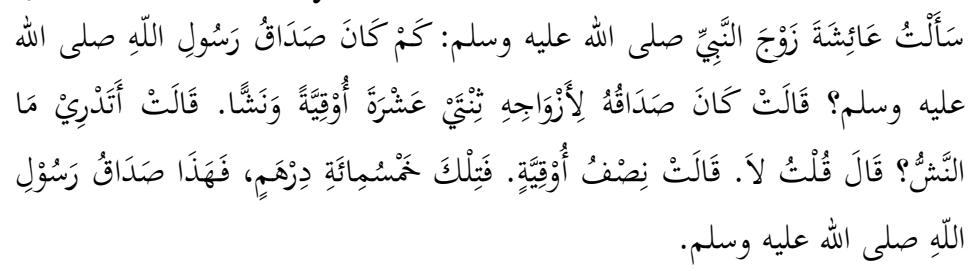

Terjemahan: Aku telah bertanya kepada Saidatina ' $\bar{A}$ 'ishah, isteri Rasulullah: berapakah mas kahwin Rasulullah? ' $\bar{A}$ 'ishah berkata: Mas kahwin Rasulullah untuk isteri-isteri baginda adalah sebanyak 12 uqiyyah dan satu nashsh. ' $\bar{A}$ 'ishah bertanya: adakah kamu tahu, berapakah yang dikatakan satu nashsh? Lalu berkata (Abu Salamah) aku berkata: tidak. 'A''ishah berkata: Satu per dua uqiyyah. Jumlahnya adalah lima ratus dirham dan itulah mas kahwin Rasulullah untuk isteri-isteri baginda. ${ }^{13}$

Menurut al-Nawāwī, 1 uqiyyah Hijaz menyamai 40 dirham. ${ }^{14}$ Ini bermakna 12 uqiyyah adalah berjumlah 480 dirham. Apabila ditambah dengan satu nashsh iaitu satu per dua uqiyyah yang menyamai 20 dirham, jumlah kesemuanya adalah 500 dirham. 1

13 Hadith Riwayat Muslim, Kitāb al-Nikāḥ, Bāb al-Ṣadāq wa Jawāz Kawnuh Ta' 'īm Qur'ān wa Khātim Ḥad̄̄d wa Ghayr Dhālik min Qalīl wa Kathīr wa Istiḥbāb Kawnuh Khams Mi'ah Dirham li man lā Yajhaf bih, no. Hadith 3489, dan al-Nasā̄'1, Kitāb al-Nikāḥ: Bāb al-Qisṭ fì al-Aṣdiqah, no. Hadith 3350. Lihat Abū al-Ḥusayn Muslim bin al-Ḥujjāj bin Muslim, "Șaḥịh Muslim", dalam Mawsū'at al-Hadīth al-Sharīf al-Kutub al-Sittah, 915 dan Abū 'Abd al-Raḥmān Aḥmad bin Shu'ayb al-Nasā'̄̄, Sunan al-Nasā'̄', dalam Mawsü'at al-Hadìth al-Sharīf, 2304.

14 Abū Zakariyyā Yahyā bin Sharf al-Nawāwī, Șāḥịh Muslim bi Sharh alNawāwī (Kaherah: Dār al-Taqwā, t.t.), 10:201. 
dirham jika dinilai dari sudut timbangan perak, adalah menyamai 2.975 gram. ${ }^{15}$ Ini bermakna 500 dirham adalah menyamai dengan nilai bagi 1487.5 gram perak.

Selain hadis di atas, Saidina 'Umar al-Khattab r.a juga menyatakan secara umum mas kahwin isteri dan puteri Rasulullah SAW ketika menyampaikan khutbah:

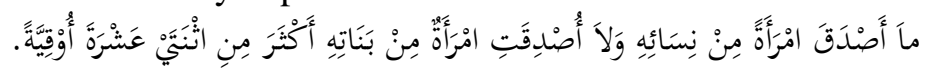

Terjemahan: "Nabi tidak pernah memberi mas kahwin kepada mana-mana isterinya, dan puteri-puteri baginda juga tidak diberikan mas kahwin melebihi 12 uqiyyah".

Apa yang membezakan antara dua riwayat ini ialah, kekurangan satu nashsh dalam hadis yang diriwayatkan oleh Saidina 'Umar al-Khattab r.a, berbanding dengan riwayat Saidatina ' $\bar{A}$ 'ishah r.a. Ini bermakna jumlah yang dinyatakan oleh Saidina 'Umar al-Khattab r.a adalah bersamaan 480 dirham kurang 20 dirham dari jumlah yang dinyatakan oleh Saidatina ' $\overline{\mathrm{A}}$ 'ishah r.a.

Seterusnya terdapat beberapa buah hadis yang khusus menceritakan mas kahwin bagi isteri-isteri Rasulullah SAW. Abū Sa'īd al-Khudrī telah meriwayatkan:

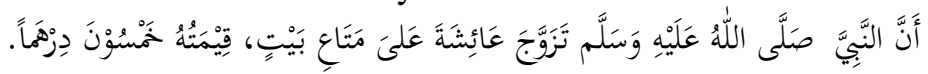

Terjemahan: "Nabi SAW telah menikahi 'A' ishah dengan mas kahwin perkakas rumah yang bernilai 50 dirham". ${ }^{17}$

Dalam riwayat di atas, dinyatakan bahawa mas kahwin bagi Saidatina ' $\bar{A}$ 'ishah r.a adalah perkakas rumah yang bernilai 50 dirham. Berbeza dengan mas kahwin Saidatina ' $\overline{\mathrm{A}}$ 'ishah r.a, Saidatina Umm Habībah r.a pula diriwayatkan telah menerima mas kahwin jauh lebih tinggi. 'Urwah pernah meriwayatkan:

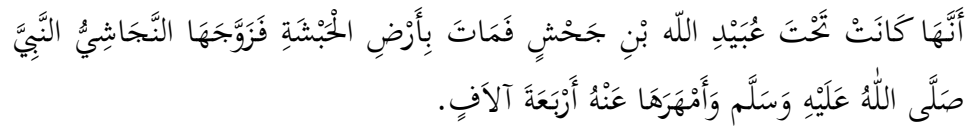

15 'Alī Jum'ah Muhammad, al-Makāyīl wa al-Mawāzīn al-Shar'iyyah (Kaherah: al-Quds, 2001), 19.

16 Hadith Riwayat Ibn Mājah, Abwāb al-Nikāḥ, Bāb Șadāq al-Nisā', no. Hadith 1887. Lihat Abū 'Abd Allāh Muḥammad bin Yazīd al-Rab‘̄i bin Mājah, "Sunan Ibn Mājah”, dalam Mawsu'ah al-Hadīth al-Sharīf, 2590.

17 Hadith Riwayat Ibn Mājah, Abwāb al-Nikāḥ, Bāb Șadāq al-Nisā', no. Hadith 1890. Lihat Ibn Mājah, "Sunan Ibn Mājah", dalam Mawsū'at al-Hadìth alSharif, 2590. 
Terjemahan: "Sesungguhnya dia (Ummu Habibah) adalah di bawah tanggungan 'Ubayd Allāh bin Jahsh. Lalu suaminya meninggal dunia di Habsyah. Kemudian beliau telah dinikahkan oleh raja Najashi dengan Rasulullah SAW. Dia (Najashi) telah memberinya mas kahwin kepadanya (Umm Habībah) sebanyak 4000. ${ }^{18}$

Dalam riwayat ini, dinyatakan bahawa raja Najashi telah menjadi wakil dalam urusan pernikahan Rasulullah SAW dengan Saidatina Ummu Habibah r.a. Beliau telah memberikan mas kahwin sebanyak 4000 dirham bagi pihak baginda kepada Saidatina Ummu Habibah r.a. ${ }^{19}$

Selain bayaran berbentuk harta, Rasulullah SAW juga pernah membayar mas kahwin berbentuk manfaat dengan membebaskan bakal isteri baginda daripada tawanan perang. Al-Sya'bī meriwayatkan:

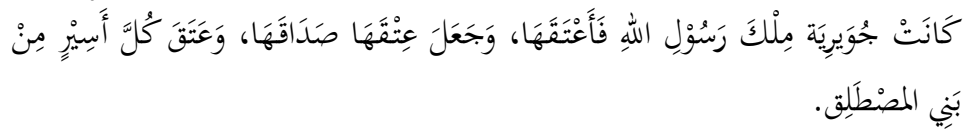

Terjemahan: "Juwayriyah merupakan ahli tawanan perang Rasulullah, lalu baginda membebaskannya. Baginda telah menjadikan pembebasan tersebut sebagai mas kahwin Juwayriyah, dan baginda telah membebaskan setiap tawanan perang Bani Mustaliq". ${ }^{20}$

Riwayat di atas telah mengisahkan Rasulullah SAW pernah membebaskan Saidatina Juwayriyah binti Harith r.a yang merupakan salah seorang tawanan perang Bani al-Mustaliq di bawah penguasaan seorang kaum Ansar bernama Thābit bin Qays.

18 Hadith Riwayat Abū Dāwud, Kitāb al-Nikāḥ, Bāb al-Șadāq. no. Hadith 2107, dan al-Nasā'̄', Kitāb al al-Nikāḥ, Bāb al-Qisț fî al-Așdiqah, no. Hadith 3352. Lihat Abū Dāwud Sulaymān bin al-'Ash'ath bin Isḥāq al-Sajistān̄̄, "Sunan Abū Dāwud", dalam Mawsū'at al-Hadīth al-Sharîf, 1378, dan al-Nasā'̄̄, "Sunan al-Nasā'̄̄", dalam Mawsū'at al-Hadìth al-Sharīf, 2304.

19 Abū al-Ṭayyīb Muhammad Shams al-Ḥaqq al-'Az̄ìm Ābādī, 'Awn al-Ma 'būd Sharh Sunan Abī Dāwūd, ed. 'Abd al-Raḥmān Muhammad 'Uthmān (t.tp.: alMaktabah al-Salafiyyah, 1979), 6:137.

20 Hadith Riwayat al-Ṭabrān̄̄, Mā Intahā Ilaynā min Musnad al-Nisā’ Rawayn an al-Rasūl, Juwayriyah bint al-Ḥārìth bin Abī Dirār bin al-Ḥārīth bin ' $\bar{A}$ 'idz bin Ab̄̄ Dirār bin al-Harith bin 'A'idz bin Mālik bin al-Muștaliq bin Khuzā'ah wa Ism al-Mușțaliq Khuzaymah, no. Hadith 154. Lihat Abī alQāsim Sulaymān bin Aḥmad al-Ṭabrān̄̄, al-Mu ‘jam al-Kabīr (Beirut: Mu'assasah al-Rayyān, 2010), 16:5644. 
Thābit bin Qays telah menetapkan harga yang agak tinggi bagi pembebasan Saidatina Juwayriyah bint al-Harīth r.a. Memandangkan bimbang terhadap kesan penentuan harga pembebasan yang terlalu tinggi, beliau telah mengadu kepada Rasulullah SAW tentang kedudukannya ketika itu. Baginda lalu menawarkan untuk membebaskan dan mengahwininya. ${ }^{21}$ Dalam kisah yang lain, ketika memperisterikan Saidatina Safiyyah binti Huyayy r.a, Rasululullah SAW juga turut membebaskan beliau dari tawanan perang. Anas bin Mālik r.a telah meriwayatkan:

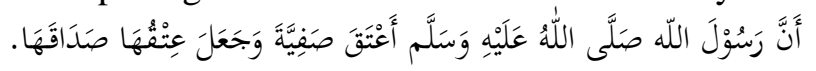

Terjemahan: "Sesungguhnya Rasulullah SAW telah membebaskan Safiyyah dan menjadikan pembebasan tersebut sebagai mas kahwin untuknya". 22

Saidatina Safiyyah binti Huyayy r.a merupakan seorang tawanan perang Khaybar sebelum berkahwin dengan Rasulullah SAW. Setelah bapanya dan suaminya mati di dalam perang tersebut, beliau ditawarkan oleh Rasulullah SAW sama ada untuk memeluk Islam dan menjadi isteri kepada baginda, atau kekal dalam agama Yahudi. Saidatina Safiyyah binti Huyayy r.a telah membuat pilihan untuk memilih agama Islam dan Rasulullah SAW kemudiannya terus membebaskan dan berkahwin dengan bermas kahwinkan pembebasan tersebut. ${ }^{23}$

Apa yang dapat dirumuskan di sini, secara umumnya, mas kahwin yang pernah diberikan oleh Rasulullah SAW adalah tidak melampaui 500 dirham. Namun secara khususnya, ia adalah berbeza dari sudut nilai dan bentuk di antara setiap isteri-isteri baginda. Ia dapat diringkaskan dalam jadual dibawah:

21 Abū Ja‘far Muhammad bin Jarīr al-Ṭabarī, Tārīkh al-Ṭabarī al-Ma 'rūf bi Tārīkh al-Umam wa al-Mulūk (Beirut: Mu'assasah al-A'lāmī, 1983), 2:264.

22 Hadith Riwayat al-Bukhārī, Kitāb al-Nikāḥ, Bāb Man Ja'ala 'Itq al-Amah Șadāqahā, no. Hadith 5086 dan al-Nasā'̄̄, Kitab al al-Nikāḥ, Bāb al-Tazwīj 'alā al-'Itq, no. Hadith 3344. Lihat al-Bukhārī, "Șaḥị̣ al-Bukhārī", dalam Mawsū'at al-Hadīth al-Sharīf, 440 dan al-Nasā'̄̄, "Sunan al-Nasā'̄̄", dalam Mawsü'at al-Hadīth al-Sharīf, 2304.

23 'Abd al-Hafiz al-Farghalī, Hamzah al-Nashratī dan 'Abd al-Hamīd Musțafā, Sïrah Āl Bayt al-Nabī (t.tp.: al-Maktabah al-Qayyimah, t.t.), 1:224. 
Jadual 1: Mas Kahwin Isteri-isteri Rasulullah SAW

\begin{tabular}{|c|l|l|l|}
\hline Bil & \multicolumn{1}{|c|}{ Nama } & \multicolumn{1}{|c|}{ Mas Kahwin } & \multicolumn{1}{c|}{ Penjelasan } \\
\hline 1. & $\begin{array}{l}\text { Saidatina } \\
\text { 'Á'ishah } \\
\text { r.a }\end{array}$ & $\begin{array}{l}\text { Perkakas } \\
\text { rumah bernilai } \\
50 \text { dirham }\end{array}$ & $\begin{array}{l}\text { Perbelanjaan tidak } \\
\text { melampaui 500 dirham } \\
\text { berbentuk barang yang } \\
\text { bermanfaat }\end{array}$ \\
\hline 2. & $\begin{array}{l}\text { Saidatina } \\
\text { Umm } \\
\text { Habībah } \\
\text { r.a }\end{array}$ & 4000 dirham & $\begin{array}{l}\text { Perbelanjaan melebihi 500 } \\
\text { dirham kerana ia } \\
\text { ditanggung oleh raja } \\
\text { Najashi }\end{array}$ \\
\hline 3 & $\begin{array}{l}\text { Saidatina } \\
\text { Juwayriya } \\
\text { h binti } \\
\text { Harith r.a }\end{array}$ & $\begin{array}{l}\text { Pembebasan } \\
\text { daripada } \\
\text { tawanan } \\
\text { perang }\end{array}$ & $\begin{array}{l}\text { Bersesuaian dengan } \\
\text { kedudukan Saidatina } \\
\text { Juwayriyah binti Harith r.a } \\
\text { sebagai salah seorang } \\
\text { tawanan perang Bani al- } \\
\text { Mustaliq }\end{array}$ \\
\hline 4. & $\begin{array}{l}\text { Saidatina } \\
\text { Safiyyah } \\
\text { binti }\end{array}$ & $\begin{array}{l}\text { Pembebasan } \\
\text { daripada } \\
\text { tawanan } \\
\text { perang }\end{array}$ & $\begin{array}{l}\text { Bersesuaian dengan } \\
\text { kedudukan Saidatina } \\
\text { Safiyyah binti Huyayy r.a } \\
\text { sebagai salah seorang }\end{array}$ \\
\hline
\end{tabular}

\section{Penganjuran Walimah oleh Rasulullah SAW}

Rasulullah SAW diriwayatkan mengadakan walimat al-'urs untuk isteri-isteri baginda dengan pelbagai sajian. Terdapat beberapa riwayat hadis yang mengisahkan tentang walimat al-'urs yang pernah dilakukan oleh baginda. Saidina Anas r.a telah meriwayatkan:

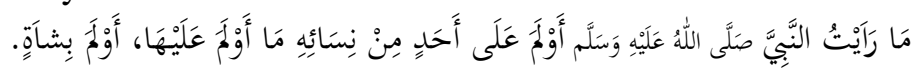

Terjemahan: "Aku tidak pernah melihat nabi Muhammad mengadakan walimah untuk isteri-isteri baginda seperti mana yang telah dilakukan untuk Zaynab bint Jahsh. Baginda telah mengadakan walimah untuknya dengan seekor kambing". ${ }^{24}$

24 Hadith Riwayat al-Bukhārī, Kitāb al-Nikāḥ, Bāb Man Awlam 'alā Ba'ḍ Nisā'ih Akthar min Ba‘ḍ, no. Hadith 5171 dan Muslim, Kitāb al-Nikāh, Bāb Zawāj Zaynab binti Jạ̣sh wa Nuzūl al-Hijāb wa Ithbāt Walīmat al-'Urs, no. Hadith 3503. Lihat al-Bukhārī, "Șah̄ịh al-Bukhārī”, dalam Mawsū'at alHadīth al-Sharīf, 447 dan Muslim, "Șahịḥ Muslim", dalam Mawsū'at alHadìth al-Shariff, 917. 
Berdasarkan hadis di atas, Saidina Anas r.a telah menggambarkan walimah Rasulullah SAW dengan Saidatina Zaynab binti Jahsh r.a sebagai sebuah walimah yang paling meriah dari aspek hidangan. ${ }^{25}$ Ia juga menunjukkan sajian yang paling mewah pernah dihidangkan oleh baginda adalah seekor kambing. Namun, menurut Ibn Hajr al-'Asqalān̄̄, penafian Anas r.a bahawa Nabi Muhammad SAW tidak pernah mengadakan walimah kepada isteri-isteri lain setanding dengan walimah bagi Saidatina Zaynab bint Jahsh r.a bukan semata-mata menunjukkan maksud demikian, kerana ia boleh memberi pelbagai andaian. Penafian itu mungkin sekadar apa yang diketahui oleh beliau sahaja. Ia juga boleh diandaikan bagi menggambarkan keberkatan walimah tersebut sehinggakan kaum muslimin yang hadir pada majlis itu telah merasa kenyang hanya dengan hidangan roti dan seekor kambing. Menurut Ibn Hajar lagi, adalah satu perkara yang tidak mustahil Rasulullah SAW mengadakan walimah dengan hidangan yang melebihi seekor kambing. Ketika walimah Rasulullah SAW dengan Saidatina Maimunah bint Haris r.a yang berlaku dalam umrah qadha' selepas penaklukan Khaybar, baginda telah mengundang penduduk Mekah untuk menghadirinya. Menurut Ibn Hajr, adalah kurang munasabah walimah tersebut tidak melebihi seekor kambing kerana pada ketika itu, kehidupan Rasulullah SAW telah lapang dan Allah SWT telah melapangkan kaum muslimin semenjak pembukaan Khaybar. ${ }^{26}$

Dalam riwayat lain, Saidina Anas r.a meriwayatkan walimah sempena perkahwinan baginda dengan Saidatina Zaynab bint Jahsh r.a turut dihidangkan dengan roti. ${ }^{27}$ Beliau juga meriwayatkan bahawa ibunya, Ummu Sulaym telah menyediakan hays, sebagaimana berikut:

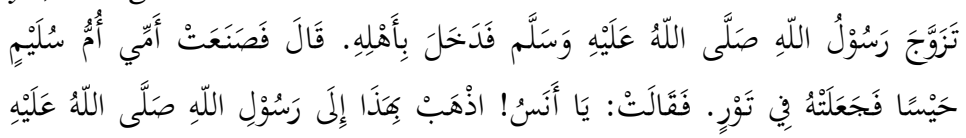

25 'Atiyyah Saqr, Mawsū'at al-Usrah Taht Ri'ayat al-Islām (Kaherah: Maktabah Wahbah, 2003), 1:497.

26 Aḥmad bin 'Alī bin Ḥajr al-'Asqalān̄i, Fath al-Bārī bi al-Sharh Ṣahīh alBukhārī (Kaherah: Maktabah al-Mișr, 2001), 9:193.

27 Lihat hadith riwayat Muslim, Kitāb al-Nikāḥ, Bab Zawāj Zaynab bint Jahsh wa Nuzūl al-Hijāb wa Ithbāt Walimat al-'Urs, no. Hadith 3504. Lihat Muslim, "Ṣaḥịh Muslim", dalam Mawsū'at al-Hadīth al-Sharīf, 917. 


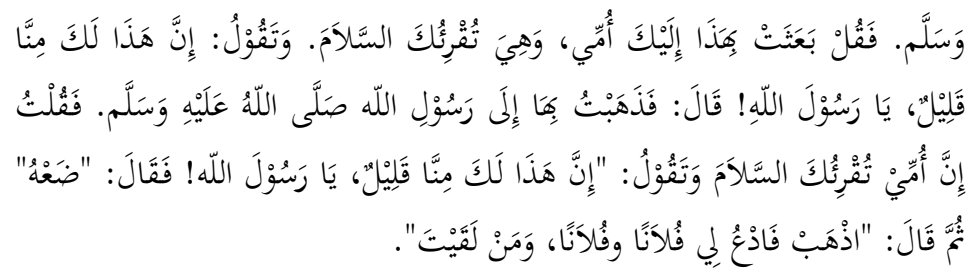

Terjemahan: Rasulullah SAW telah berkahwin (dengan Saidatina Zaynab bint Jahsh), kemudian baginda telah bersama dengannya. Anas berkata: ibuku Umm Sulaym telah membuat hays dan dia telah meletakkannya di dalam sebuah bekas. Lalu dia berkata: "Wahai Anas, bawalah makanan ini kepada Rasulullah SAW dan katakanlah kepada baginda, ibu saya telah mengirimkan kepadamu dan dia menyampaikan salam kepadamu. Ummu Sulaym berkata, ini adalah untuk kamu wahai Rasulullah sedikit makanan dari kami". Kemudian aku pergi bertemu Rasulullah SAW dan berkata: "Ibuku menyampaikan salam kepadamu, dan dia berkata, ini adalah untuk kamu wahai Rasulullah sedikit makanan dari kami”. Sabda Rasulullah SAW: "letakkanlah ia", kemudian baginda bersabda lagi: "pergilah dan undanglah untukku si fulan dan si fulan, dan setiap orang yang kamu jumpa. ${ }^{28}$

Kisah dalam hadis di atas menggambarkan Ummu Sulaym telah menyediakan sejenis menu yang disebut sebagai hays iaitu sejenis makanan yang diadun dari keju, kurma dan minyak sapi. ${ }^{29}$

Penyediaan sajian bermenukan hays turut dijadikan menu dalam walimah perkahwinan Rasulullah SAW dengan Saidatina Safiyyah bint Huyayy r.a sebagaimana yang diriwayatkan oleh Saidina Anas r.a:

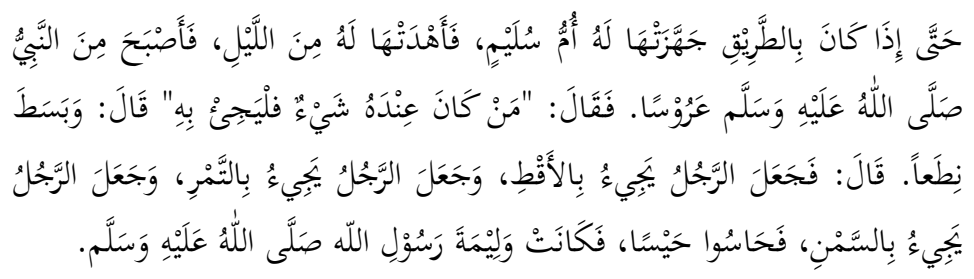

28 Hadith riwayat Muslim, Kitab al-Nikāḥ, Bāb Zawāj Zaynab bint Jahsh, wa Nuzūl al-Hijāb, wa Ithbāt Walimat al-'Urs, no. Hadith 3507. Lihat Muslim, "Ṣahịḥ Muslim", dalam Mawsū'at al-Hadìth al-Sharīf, 916.

29 Ibn Hajr al-'Asqalānī, Fath al-Bārī bi al-Sharh Ṣah̄̄ḥ al-Bukhārī, 9:653. 
Terjemahan: Ketika dalam perjalanan pulang, Umm Sulaym mempersiapkan (Safiyyah bint Huyayy) untuk perkahwinannya dengan nabi, kemudian beliau diserahkan kepada nabi pada malam itu. Maka pada keesokan paginya, nabi telah menjadi seorang mempelai, lalu bersabda: "Sesiapa yang mempunyai sedikit makanan, hendaklah dibawa". Lalu ditebarkan sebuah tikar dari kulit. Ada yang membawa keju, ada yang membawa kurma dan ada yang membawa minyak sapi. Kesemuanya diadun menjadi hays dan itulah walimah Rasulullah SAW. ${ }^{30}$

Dalam hadis di atas, para sahabat telah bekerjasama dalam penyediaan hidangan untuk walimah. Bahan makanan yang dibawa oleh mereka telah diadun dan dijadikan hays. Dalam riwayat lain, Saidina Anas r.a ada menyebut antara hidangan yang disediakan sempena walimah tersebut adalah berasaskan kurma dan sawiq. ${ }^{31}$ Sawiq adalah sejenis tepung yang digoreng. Pada kebiasaannya ia merupakan bekalan makanan bagi orang yang ingin bermusafir dan menu ini amat mudah dan segera untuk disediakan. $^{32}$

Selain sajian berasaskan daging, roti, kurma, tepung, keju dan minyak sapi, Rasulullah SAW juga pernah diriwayatkan menyajikan sajian berasaskan barli. Safiyyah binti Shaybah pernah berkata:

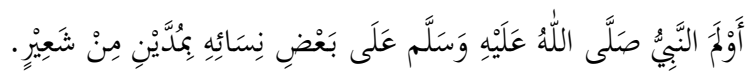

Terjemahan: "Nabi Muhammad SAW pernah mengadakan walimah untuk sebahagian isteri-isteri baginda dengan dua cupak barli". ${ }^{33}$

Riwayat di atas tidak menyebut nama isteri Rasulullah SAW. Namun, menurut Ibn Hajar, isteri yang paling hampir

30 Hadith Riwayat Muslim, Kitāb al-Nikāḥ, bāb Faḍilah I'taqih Ammah Thumma Yatazawwajuha, no. Hadith 3497. Lihat Muslim, "Șaḥị̣ Muslim”, dalam Mawsū'at al-Hadīth al-Sharīf, 916.

31 Hadith Riwayat Ibn Majah, Abwāb al-Nikāh, Bab al-Walimah, no. Hadīth 1909. Lihat Abū 'Abd Allāh Muḥammad bin Yazīd al-Rab'i bin Mājah, "Sunan Ibn Majah”, dalam Mawsū'at al-Hadìth al-Sharīf, 2591.

32 Muhammad Murtaḍā al-Zabīīi, Tāj al- 'Arus min Jawāhir al-Qāmūs (t.tp.: Matba'ah al-Khayriyyah, t.t.), 6:388.

33 Hadith Riwayat al-Bukhārī, Kitāb al-Nikāḥ, bāb Man Awlam 'alā Ba'd Nisā'īh Akthar min Ba'd, no. Hadith 5172. Lihat al-Bukhārī, "Ṣaḥị̣̣ alBukhārī”, dalam Mawsū'at al-Hadìth al-Sharīf, 447. 
dimaksudkan adalah Saidatina Umm Salamah r.a. Ia berdasarkan kepada apa yang telah dinukilkan oleh Ibn Sa'd dari gurunya alWāqidī yang menyatakan Umm Salamah pernah mengisahkan walimah beliau telah menghidangkan menu berasaskan barli. ${ }^{34}$

Daripada perbincangan di atas, dapat disimpulkan bahawa penyediaan menu dalam walimah Rasulullah SAW adalah terdiri daripada pelbagai hidangan mengikut kesesuaian semasa. Ia dapat dirumuskan seperti dalam jadual di bawah:

Jadual 2: Hidangan Sempena Walimah Rasulullah SAW

\begin{tabular}{|c|c|c|c|}
\hline Bil. & Nama & Hidangan & Penjelasan \\
\hline 1. & $\begin{array}{l}\text { Saidatina } \\
\text { Zaynab } \\
\text { bint } \\
\text { Jahsh r.a }\end{array}$ & $\begin{array}{l}\text { - Kambing } \\
\text { - Roti } \\
\text { - Hays (sejenis } \\
\text { makanan yang diadun } \\
\text { dari keju, kurma dan } \\
\text { minyak sapi) } \\
\end{array}$ & $\begin{array}{l}\text { Diriwayatkan } \\
\text { sebagai walimah } \\
\text { yang paling } \\
\text { mewah pernah } \\
\text { dilakukan oleh } \\
\text { Rasulullah SAW }\end{array}$ \\
\hline 2. & $\begin{array}{l}\text { Saidatina } \\
\text { Safiyyah } \\
\text { bint } \\
\text { Huyayy } \\
\text { r.a }\end{array}$ & $\begin{array}{l}\text { - Hays (sejenis } \\
\text { makanan yang diadun } \\
\text { dari keju, kurma dan } \\
\text { minyak sapi) } \\
\text { - Kurma } \\
\text { - Sawiq (sejenis tepung } \\
\text { yang digoreng) }\end{array}$ & $\begin{array}{l}\text { Bersesuaian } \\
\text { dengan situasi } \\
\text { permusafiran }\end{array}$ \\
\hline 5. & $\begin{array}{l}\text { Saidatina } \\
\text { Ummu } \\
\text { Salamah } \\
\text { r.a }\end{array}$ & Dua cupak barli & \\
\hline
\end{tabular}

\section{Konsep Perbelanjaan Perkahwinan Mengikut Sunnah Rasulullah SAW}

Hasil daripada penelitian terhadap apa yang telah dilalui oleh Rasulullah SAW dalam urusan pemberian mas kahwin dan penganjuran walimah sempena perkahwinan baginda, didapati terdapat beberapa konsep berbelanja dalam hal berkaitan persediaan perkahwinan telah diketengahkan oleh baginda. Konsep-konsep yang dimaksudkan adalah sebagai mana berikut:

34 Ibn Ḥajr al-'Asqalānī, Fath al-Bārī bi al-Sharh Șah̄ịh al-Bukhārī, 9:195. 


\section{Perbelanjaan Bermanfaat}

Rasulullah SAW mengutamakan unsur manfaat dalam menguruskan perbelanjaan perkahwinan. Hal keadaan ini dapat dilihat daripada bentuk mas kahwin yang telah diberikan kepada isteri-isteri baginda apabila kesemuanya mempunyai nilai manfaat. Secara keseluruhan, mas kahwin Rasulullah SAW telah digambarkan tidak mengurangi nilaian 500 dirham sebagai mana yang pernah diriwayatkan oleh Abū Salamah bin 'Abd alRaḥman. ${ }^{35}$ Walau pun nilaian tersebut bukan semestinya mata wang dirham, namun apa yang dijadikan mas kahwin oleh baginda itu adalah harta yang sememangnya dapat memberi manfaat kepada isteri baginda. Apa yang diterima oleh Saidatina ' $\bar{A}$ ' ishah r.a iaitu perkakas rumah bernilai 500 dirham, ${ }^{36}$ merupakan antara harta yang diperlukan oleh isteri yang baharu berkahwin bagi memberi keselesaan kehidupan rumah tangga. Pembebasan Saidatina Safiyyah binti Huyayy r. ${ }^{37}$ dari tawanan perang turut memberi manfaat yang besar kepada beliau, kerana kehidupan sebagai seorang tawanan perang adalah satu kehidupan yang terikat dan tidak bebas. Pemberian mas kahwin dalam bentuk manfaat seperti ini diterima dalam Islam, ${ }^{38}$ kerana meski pun ia

35 Lihat hadith Riwayat Muslim, Kitab al-Nikāh, Bāb al-Ṣadaq wa Jawāz Kawnuh Ta'līm Qur'ān wa Khatim Hadid wa Ghayr Dhālik min Qalīl wa Kathīr wa Istiḥbab Kawnuh Khams Mi'ah Dirham li man la Yajhaf bih, no. Hadith 3489, dan al-Nasā̄î, Kitāb al-Nikāḥ, Bāb al-Qisț fī al-Asdiqah, no. Hadith 3350. Lihat Muslim, "Șahịh Muslim", dalam Mawsū'at al-Hadìth alSharīf, 915 dan al-Nasā'̄̄, "Sunan al-Nasā'î", Mawsū' at al-Hadìth al-Sharīf, 2304.

36 Lihat hadith Riwayat Ibn Majah, Abwāb al-Nikāḥ, Bāb Șadaq al-Nisā', no. Hadith 1890. Lihat Ibn Majah, "Sunan Ibn Majah", dalam Mawsū'at alHadìth al-Sharîf, 2590.

37 Lihat hadith Riwayat al-Bukhari, Kitab al-Nikāḥ, Bab Man Ja'alā 'Itq alAmah Sadaqaha, no. Hadith 5086 dan al-Nasā’̀̄, Kitab al al-Nikāḥ, Bab alTazwīj 'alā al-'Itq, no. Hadith 3344. Lihat al-Bukhārī, "Șaḥị̣ al-Bukhārī”, dalam Mawsū'at al-Hadìth al-Sharīf, 440 dan al-Nasā'̄', Sunan al-Nasā'̄', dalam Mawsū'at al-Hadīth al-Sharīf, 2304.

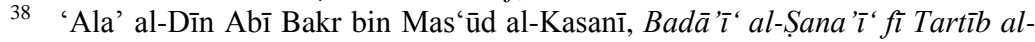
Sharā 'c (Beirut: Dār Ihyā' al-Turath al-'Arabī, 2000), 2:567; Ibn Qudamah, al-Mughnī, ed. 'Abd Allāh bin 'Abd al-Muḥ̣sin al-Turk dan 'Abd al-Fattāḥ Muhammad al-Halw (Riyadh: Dār 'Alam al-Kutub, 1986), 7:101; Muḥammad bin Idrīs al-Shāfi'ī, al-Umm (Mansoura: Dār al-Wafā', 2001), 6:153. 
bukan berbentuk harta, namun apa yang diterima oleh isteri adalah sesuatu yang boleh memberi faedah kepadanya.

Jika disoroti kepada majlis walimah Rasulullah SAW, diantara menu yang dihidangkan adalah hays, sawiq, sajian berasaskan kambing, roti dan barli. Menu-menu ini adalah bersesuaian dengan adat pemakanan masyarakat Arab ketika itu, bahkan merupakan makanan harian mereka. Ia sudah tentu memberi manfaat kepada para tetamu yang hadir pada majlis tersebut. Kemanfaatan sajian adalah bergantung kepada kesesuaian sajian kepada masyarakat setempat. Sajian yang bukan merupakan adat makanan masyarakat tempatan tidak akan memberi manfaat kepada tetamu yang hadir.

Apa yang dapat dinyatakan di sini, unsur manfaat telah dititkberatkan dalam kedua-dua elemen mas kahwin dan walimah 'al-urs Rasulullah SAW. Baginda sesekali tidak pernah membelanjakan harta untuk sesuatu yang tidak mendatangkan sebarang manfaat. Mas kahwin yang diberikan telah mendatangkan manfaat kepada isteri-isteri baginda, manakala menu-menu yang dihidangkan dalam walimah pula telah memberi faedah kepada para tetamu yang hadir. Ini menggambarkan Rasulullah SAW amat mementingkan impak daripada perbelanjaan perkahwinan. Harta yang dibelanjakan untuk tujuan perkahwinan tidak sewajarnya disia-siakan, malah kemanfaatannya perlu dicapai oleh kedua-dua pihak iaitu orang yang membelanja dan orang yang menerima.

\section{Perbelanjaan Mengikut Tahap Kemampuan}

Rasulullah SAW telah memaparkan konsep berbelanja berdasarkan kemampuan dalam menguruskan perbelanjaan perkahwinan. Dalam sirah perkahwinan baginda dengan Saidatina Safiyyah binti Huyayy r.a yang diadakan ketika dalam perjalanan pulang dari perang Khaybar, ${ }^{39}$ sajian yang disediakan adalah sejenis menu ringkas yang berasaskan keju, kurma dan minyak sapi. Bahan-bahan tersebut telah diadun dan dibentuk sebagai hays, ${ }^{40}$ iaitu sejenis menu bagi masyarakat Arab ketika itu. Hidangan tersebut adalah bersesuaian dengan kemampuan

39 Ibn Hajr al-'Asqalānī, Fath al-Bārī bi al-Sharh Șaḥ̄ḥ al-Bukhāri, 7:680.

40 Ibn Hajr al-'Asqalānī, Fatḥ al-Bārī bi al-Sharḥ Ṣaḥ̄ḥ al-Bukhāri, 9:653. 
baginda yang masih berada dalam keadaan musafir ${ }^{41}$ dan serba kekurangan ketika itu. Pelaksanaan walimah dalam keadaan musafir sudah tentu lebih sukar berbanding dengan walimah yang diadakan ketika luar musafir dari aspek persiapan sajian dan sebagainya. Ia berbeza dengan apa yang dihidangkan ketika walimah sempena perkahwinan baginda dengan Saidatina Zaynab binti Jahsh r.a yang berasaskan seekor kambing. ${ }^{42}$

Apa yang jelas, Rasulullah SAW telah mementingkan unsur kemampuan dalam menyediakan hidangan untuk walimah. Penerapan konsep ini bukan sahaja berlaku ke atas perbelanjaan perkahwinan Rasulullah SAW, malah baginda pernah memberi teguran kepada seorang sahabat yang telah membayar mas kahwin kepada isterinya dengan satu kadar yang tidak sesuai dengan tahap kemampuan beliau. ${ }^{43}$ Dalam membincangkan konsep kemampuan dalam berbelanja, Ibn Hajr menyatakan penyediaan hidangan untuk walimah mengikut tahap kemampuan adalah satu perkara yang disunatkan dalam Islam. $^{44}$ Al-Nawāwī pula menyatakan adalah makruh bagi seorang lelaki membayar mas kahwin kepada isterinya dengan kadar yang melebihi tahap kemampuan dirinya sendiri. Ini kerana ia akan menyukar pihak suami untuk memenuhi bayaran tersebut. ${ }^{45}$ Melalui penerapan konsep berbelanja mengikut kemampuan, perbelanjaan perkahwinan secara keseluruhannya akan lebih terkawal dan dapat mengelakkan daripada berlakunya perbelanjaan di luar batas kemampuan.

41 Rafif 'Abd al-'Az̄̄z al-Sibbagh, Hafl al-Zifaf fì al-Fiqh al-Islāmī Dawābituhu wa Ahkamuh (Tesis Sarjana, Universiti Damsyiq, Syria, 2004), 23.

42 Hadith Riwayat al-Bukhārī, Kitab al-Nikāh, Bab Man Awlam 'alā Ba'd Nisa'ih Akthar min Ba'd, no. Hadith 5171 dan Muslim, Kitāb al-Nikāḥ, Bab Zawāj Zaynab bint Jahsh wa Nuzūl al-Hijāb wa Ithbāt Walīmat al-'Urs, no. Hadith 3503. Lihat al-Bukhārī, "Șah̄ịh al-Bukhārī", dalam Mawsū'at alHadīth al-Sharīf, 447 dan Muslim, "Ṣahịị Muslim", dalam Mawsū'at alHadīth al-Sharîf, 917.

43 Lihat hadith riwayat Muslim, Kitab al-Nikāḥ, Bab Nadb Man 'Araḍ Nikāḥ alMar'ah ilā an Yanzur ilā Wajhiha wa Kaffayha Qabl Khitbatiha. 3486. Lihat Muslim, "Șah̄ị Muslim”, dalam Mawsū'at al-Hadīth al-Sharīf, 915.

44 Ibn Hajr al-'Asqalān̄i, Fatḥ al-Bārī bi al-Sharḥ Șah̄ịh al-Bukhārī, 9:189.

45 Al-Nawāwī, Sậ̣̄̄ Muslim bi Sharh al-Nawāwī, 9:197. 


\section{Perbelanjaan Secara Sederhana}

Perbelanjaan secara sederhana adalah perbelanjaan yang terletak di antara perbelanjaan yang mempunyai unsur kedekut dan membazir. ${ }^{46} \mathrm{Al}-\mathrm{R} a \bar{z} \overline{1}$ telah menjelaskan sikap tidak membazir dan tidak kedekut merupakan antara ciri kesederhanaan dalam mengejar kehidupan berekonomi. ${ }^{47}$ Dalam konteks perbelanjaan perkahwinan, sederhana yang dimaksudkan adalah perbelanjaan yang tidak melibatkan kos terlalu tinggi dan tidak pula terlalu rendah. Unsur kesederhanaan ini telah ditunjukkan oleh Rasulullah SAW dalam pemberian kadar mas kahwin baginda yang diriwayatkan bernilai sekitar 500 dirham. ${ }^{48}$ Ia bukanlah satu kadar yang terlalu tinggi dan juga tidak terlalu rendah. 500 dirham jika dinilai dari sudut timbangan adalah menyamai 1487.5 gram perak, kerana 1 dirham pada pandangan jumhur adalah menyamai 2.975 gram. ${ }^{49}$ Jika dinilai dengan nilaian perak semasa, 1 gram perak adalah bersamaan RM 2.07..$^{50}$ Justeru, 500 dirham atau 1487.5 gram perak adalah menyamai RM 3079.10. Jumlah tersebut pada zaman sekarang bukanlah satu kadar yang terlalu rendah, bahkan ia mampu menampung perbelanjaan bulanan untuk seisi rumah. Berdasarkan kepada statistik yang pernah dikeluarkan oleh Jabatan Perangkaan Malaysia, perbelanjaan bulanan purata isi rumah semenjak dari tahun 1993 hingga ke tahun 2010 tidak pernah melepasi RM 2,190. ${ }^{51}$ Dari aspek sebaliknya pula, nilaian kadar tersebut dianggap tidak terlampau tinggi pada zaman Rasulullah SAW, malah bersesuaian dengan nilaian kadar mas kahwin untuk

46 Surtahman Kastin Hassan dan Sanep Ahmad, Ekonomi Islam: Dasar dan Amalan (Kuala Lumpur: Dewan Bahasa dan Pustaka, 2010), 77.

47 Muhammad al-Rāzī Fakhr al-Dīn bin Diyā' al-Dīn, Tafsīr al-Fakhr al-Rāzī (Beirut: Dār al-Fikr, 1985), 20:196.

48 Lihat hadith riwayat Muslim, Kitab al-Nikāḥ, Bab al-Sadaq wa Jawāz Kawnuh Ta'līm Qur'an wa Khatim Hadid wa Ghayr Dhālik min Qalīl wa Kathīr wa Istiḥbāb Kawnuh Khams Mi'ah Dirham li Man la Yajhaf bih, no. 3489. Lihat Muslim, "Șaḥị̣ Muslim”, dalam Mawsū'at al-Hadīth al-Sharīf, 915.

49 'Alī Jum'ah Muhammad, al-Makāyil wa al-Mawāzin al-Shar 'iyyah, 19.

50 Lembaga Zakat Selangor, dicapai pada 7 Mac 2015, laman sesawang http://www.zakatselangor.com.my/.

51 Laporan Penyiasatan Perbelanjaan Isi Rumah, laman sesawang Portal Rasmi Jabatan Perangkaan Malaysia, dicapai pada 19 Januari 2015, http://www.statistics.gov.my/portal/download_household/files/Expenditure/L aporan_PIR_Report_on_HES_2009-10.pdf. 
masyarakat ketika zaman itu. ${ }^{52}$ Saidina 'Umar al-Khattab r.a dalam khutbahnya pernah melarang masyarakat meninggikan kadar mas kahwin dan menyatakan seandainya perbuatan itu adalah satu amalan mulia dalam Islam, sudah tentu ia telah dilakukan oleh Rasulullah SAW. ${ }^{53}$ Ini menunjukkan kadar mas kahwin yang pernah diberikan oleh baginda adalah satu jumlah yang tidak terlampau tinggi. Sekiranya jumlah itu merupakan satu kadar yang tinggi, Saidina 'Umar al-Khattab r.a sudah tentu tidak menjadikan mas kahwin baginda sebagai satu contoh kadar mas kahwin yang tidak melampau. Jika pada zaman Rasulullah SAW, kadar tersebut telah dianggap perbelanjaan yang tidak terlalu tinggi, maka ia lebih relevan untuk dianggap tidak terlampau tinggi pada masa sekarang.

Dalam sirah perkahwinan Rasulullah SAW, kadar mas kahwin tertinggi yang pernah diterima oleh isteri-isteri baginda adalah mas kahwin Saidatina Umm Habībah r.a. Beliau diriwayatkan telah menerima mas kahwin sebanyak 4000 dirham, ${ }^{54}$ jauh lebih tinggi dari 500 dirham. Namun, ketinggian kadar itu bukan menunjukkan kepada anjuran meninggikan mas kahwin khususnya dan perbelanjaan perkahwinan umumnya. Hal keadaan ini adalah kerana, pemberian kadar tersebut merupakan pemberian peribadi daripada raja Najashi. Dalam peristiwa perkahwinan Rasulullah SAW, Raja Najashi telah dihantar oleh baginda sebagai wakil dalam urusan pernikahan itu dan beliau telah memberikan mas kahwin sebanyak 4000 dirham bagi pihak baginda kepada Saidatina Umm Habībah r.a. ${ }^{55}$ Pemberian yang tinggi ini adalah satu penghormatan beliau kepada Rasulullah SAW.

52 Aḥmad 'Abd al-Rahīm al-Daḥlawī, Hujjat Allāh al-Balighah (Kaherah: Dār al-Jayl, 2005), 2:199.

53 Lihat hadith riwayat al-Tirmidhī, Abwāb al-Nikāḥ, Bab Mā Jā'a fĩ Muhur alNisā', no. 1114. Lihat Abū 'Isā Muhammad bin 'Isā al-Tirmidhī, "Jāmi' alTirmidhī”, dalam Mawsū'at al-Hadīth al-Sharīf, 1760.

54 Lihat hadith Riwayat Abū Dāwud, Kitab al-Nikāḥ, Bab al-Sadaq. no. Hadith 2107, dan al-Nasā'̄̄, Kitab al-Nikāḥ, Bab al-Qisț fì al-Așdiqah, no. Hadith 3352. Lihat Abū Dāwud, "Sunan Abū Dāwud", dalam Mawsū'at al-Hadīth al-Sharīf, 1378, dan al-Nasā'̀, "Sunan al-Nasā'̄̄", dalam Mawsū'at al-Hadìth al-Sharīf, 2304.

55 Al-'Aẓ̂̀m Abādī, 'Awn al-Ma 'būd Sharh Sunan Abī Dāwud, 6:137. 
Secara umumnya dapat dinyatakan bahawa Rasulullah SAW telah memaparkan konsep kesederhanaan dalam menetapkan kadar perbelanjaan perkahwinan baginda. Nilai 500 dirham yang pernah dijadikan mas kahwin untuk isteri-isteri baginda adalah satu nilai yang tidak terlampau tinggi dan juga tidak terlampau rendah, bahkan kesederhanaan itu amat sesuai dijadikan asas dalam elemen perbelanjaan perkahwinan yang lain.

\section{Perbelanjaan Secara Kerjasama}

Sirah perkahwinan Rasulullah SAW dengan isteri-isteri baginda telah memaparkan beberapa kisah yang menunjukkan wujudnya konsep tolong menolong dan kerjasama oleh para sahabat ketika baginda mengadakan walimat al-'urs. Anas bin Mālik r.a telah meriwayatkan bagaimana ibunya Umm Sulaym membantu Rasulullah SAW dalam menyediakan menu ketika walimah baginda dengan Saidatina Zaynab bint Jahsh r.a. Dalam kisah itu, Umm Sulaym telah mengadun hays di rumahnya dan meminta agar Saidina Anas r.a menghantar menu tersebut kepada Rasulullah SAW pada hari sambutan walimah baginda. ${ }^{56}$ Kerjasama yang dihulurkan oleh Umm Sulaym tidak ditolak oleh baginda, malah diterima dengan senang hati. Ini menunjukkan kerjasama dalam mengadakan walimat al-'urs adalah satu anjuran khusus dalam Islam. Al-Nawāwī dalam mengulas hadis di atas telah menyatakan adalah sunat bagi sahabat handai kepada pasangan untuk menghulurkan sebarang bentuk makanan dan hidangan bagi tujuan mengadakan walimat al- 'urs. ${ }^{57}$ Bantuan yang dihulurkan oleh kaum keluarga, jiran dan sahabat handai yang mempunyai kemampuan dari segi harta adalah lambang kepada tautan kasih sayang dan perkongsian rasa gembira dengan pasangan yang berkahwin. ${ }^{58}$

Anjuran bekerjasama bukan sahaja telah ditunjukkan oleh para sahabat seperti Umm Sulaym dan anaknya Anas bin Mālik r.a ketika membantu Rasulullah SAW, malah baginda sendiri turut

56 Hadith riwayat Muslim, Kitab al-Nikāḥ, Bab Zawāj Zaynab bint Jahsh, wa Nuzūl al-Hijāb, wa Ithbāt Walimat al-'Urs, no. Hadith 3507. Lihat Muslim, "Ṣahīḥ Muslim", dalam Mawsū'at al-Hadìth al-Sharīf, 916.

57 Al-Nawāwī, Saḥ̄h Muslim bi Sharh al-Nawāwī, 9:213.

58 'Abd Allāh Nāṣị,,Ulwan, Adāb al-Khiṭbah wa al-Zifaf wa Huquq al-Zawjayn (Kaherah: Dār al-Salām, 1983), 105. 
diriwayatkan pernah menyeru para sahabat untuk bersama-sama membantu dalam penyediaan hidangan untuk walimah baginda. Ia berlaku ketika perkahwinan Rasulullah SAW dengan Saidatina Safiyyah bint Huyayy sebagaimana yang diriwayatkan oleh Saidina Anas:

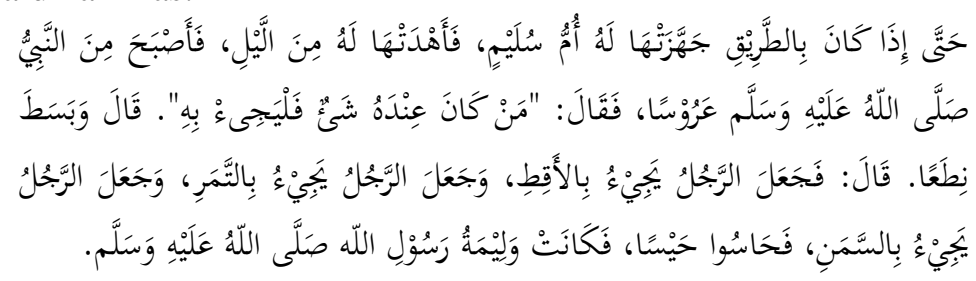

Terjemahan: Ketika dalam perjalanan pulang, Umm Sulaym mempersiapkan Safiyyah untuk perkahwinannya dengan nabi, kemudian beliau diserahkan kepada nabi pada malam itu. Maka pada keesokan paginya, nabi telah menjadi seorang mempelai, lalu bersabda: "Sesiapa yang mempunyai sedikit makanan, hendaklah dibawa". Lalu ditebarkan sebidang tikar dari kulit. Ada yang membawa keju, ada yang membawa kurma dan ada yang membawa minyak sapi. Kesemuanya diadun dan itulah jamuan Rasulullah SAW. ${ }^{59}$

Hadis ini secara khususnya telah menunjukkan anjuran konsep tolong menolong dalam urusan mengadakan walimah. ${ }^{60}$ Walau pun berkedudukan sebagai pemimpin tertinggi pada ketika itu, baginda tidak segan untuk menyatakan kepada para sahabat agar membawa makanan sempena walimah baginda dengan Saidatina Safiyyah bint Huyayy.

Apa yang dapat dirumuskan, kerjasama adalah satu perkara yang amat dianjurkan oleh Rasulullah SAW dalam menyelesaikan masalah bebanan perbelanjaan perkahwinan. Ia tidak semestinya berbentuk wang dan harta, malah boleh dihulurkan dalam pelbagai bentuk bergantung kepada tahap kemampuan individu. Amalan ini akan memberi kesan positif kepada pihak yang membantu dan yang menerima bantuan. Bagi mereka yang membantu dalam bentuk bantuan kewangan mahu pun harta, ia dikira sebagai satu amalan kebajikan dan merupakan salah satu ibadat harta. Ada pun

\footnotetext{
59 Hadith riwayat Muslim, Kitab al-Nikāḥ, Bab Faḍinat al-'I'taqih Ammatah thumma Yatazawwajuhā, no. Hadith 3497. Lihat Muslim, "Șaḥị̣ Muslim", dalam al-Shaykh, Mawsū'at al-Hadīth al-Sharīf, 915.

60 Al-Nawāwī, Șạ̄ịh Muslim bi Sharḥ al-Nawāwī, 9:207.
} 
bantuan dalam bentuk tenaga, idea dan sebagainya, tetap dikira sebagai kebajikan sosial yang amat digalakkan dalam Islam bagi mengurangkan bebanan saudara muslim. Bagi pihak yang menerima bantuan pula, ia akan menggembirakan hati mereka kerana bantuan tersebut dapat meringankan bebanan penyediaan persiapan untuk perkahwinan.

\section{Perbincangan}

Konsep perbelanjaan perkahwinan yang dibentangkan di atas adalah hasil daripada penelitian terhadap gaya dan corak perbelanjaan perkahwinan Rasulullah SAW. Pembayaran mas kahwin dan pengendalian walimat al-'urs dalam perkahwinan baginda telah dijadikan asas dalam pembentukan konsep perbelanjaan perkahwinan. Sebagai satu pembayaran wajib ${ }^{61}$ dan tuntutan sunat ${ }^{62}$ ke atas suami, elemen mas kahwin dan walimat al-'urs sewajarnya dijadikan panduan dalam pembentukan konsep tersebut, kerana selain daripada dua elemen itu, elemen perbelanjaan lain tidak mencapai tahap perbelanjaan wajib dan sunat.

Biar pun baginda tidak pernah menjelaskan secara khusus bagaimanakah cara terbaik untuk mengurus perbelanjaan bagi mas kahwin dan walimat al-'urs, namun melalui penelitian terhadap gaya perbelanjaan baginda dalam dua elemen itu, didapati baginda sememangnya menekankan empat konsep yang telah dibentangkan. Dalam konsep yang pertama, berbelanja untuk perkara yang mendatangkan manfaat sememangnya menjadi salah satu prinsip kepenggunaan dalam Islam. ${ }^{63}$ Islam hanya mengiktiraf sesuatu yang berfaedah dan boleh membawa kepada kebaikan dari

61 Ulama' bersepakat menyatakan kewajipan pembayaran mas kahwin. Lihat Ibn Qudāmah, al-Mughnī, 10:97; Abū al-Ḥasan 'Alī bin Muḥammad bin Habīb al-Mawardī, al-Hawī al-Kabīr fì Fiqh Madhhab al-Imām al-Shāfi ‘̄ (Beirut: Dār al-Kutub al-'Ilmiyyah, 1999), 9:393.

62 Jumhur ulama' menghukumkan walimah sebagai satu perintah sunat. Lihat Shams al-Dīn Muḥammad al-Dusuqī, Hệshiyah al-Dusuqī 'alā al-Sharh alKabīr li Dirdir (t.tp.: 'Isā al-Bāb̄̄ al-Ḥalabī, t.t.), 2:337; Shams al-Dīn Muḥammad bin Muḥammad al-Khațib al-Sharbin̄̄, Mughnī al-Muḥtāj ilā Ma 'rīfah Ma 'ānī Alfāz al-Minhājj (Beirut: Dār al-Kutub al-'Ilmiyyah, 1994), 4:404; Ibn Qudamah, al-Mughnī, 10:192.

63 Surtahman Kastin Hasan, Ekonomi Islam (Bangi: Universiti Kebangsaan Malaysia, 1990), 27. 
aspek kebendaan, akhlak atau kerohanian sahaja sebagai barang. ${ }^{64}$ Individu muslim dilarang mengeluarkan belanja untuk mendapatkan sesuatu yang tidak berfaedah. Konsep berbelanja mengikut tahap kemampuan pula adalah selaras dengan prinsip Islam dalam soal berkaitan pentaklifan, apabila Allah SWT tidak pernah memerintah umatnya untuk melakukan sesuatu di luar kemampuan. ${ }^{65}$ Individu muslim dianjurkan untuk mementingkan unsur keseimbangan antara pendapatan dengan perbelanjaan. ${ }^{66}$ Perbelanjaan sewajarnya dirancang berdasarkan kewangan semasa dengan mengambil kira kemampuan masing-masing dari sudut pemilikan harta. Seterusnya konsep sederhana dalam berbelanja telah dinyatakan dalam al-Qur'an melalui surah al-Isrā' apabila Allah SWT melarang sikap membazir dan kedekut. ${ }^{67}$ Berbelanja secara membazir bermakna menghabiskan harta dengan cara yang tidak membawa kepada sebarang faedah dan kebaikan, ${ }^{68}$ manakala berbelanja secara kedekut adalah satu cara untuk merosakkan harta dari aspek pembekuan apabila ia tidak diberikan kepada mereka yang mempunyai hak terhadapnya. ${ }^{69}$ Dalam konsep yang terakhir pula, bekerjasama dalam urusan perbelanjaan adalah termasuk dalam anjuran syarak yang mementingkan sikap tolong menolong sesama individu dalam melakukan kebaikan. ${ }^{70}$ Konsep kerjasama sememangnya telah menjadi satu prinsip dalam kehidupan bermasyarakat dalam Islam sebagaimana yang dapat dilihat disebalik pensyariatan zakat yang merupakan salah satu

64 Monzer Kahf, The Islamic Economy, terj. Ismail Salleh dan Mansor Jusoh (Kuala Lumpur: Pertubuhan Kebajikan Islam Malaysia, 1982), 29.

65 Abū 'Abd Allāh Muḥammad al-Qurțubī, al-Jāmi' li Ahkām al-Qur'an, ed. Muḥammad Ibrāhīm al-Hafnawī dan Mạ̣mūd Ḥāmid 'Uthmān (Kaherah: Dār al-Hadīth, 2002), 2:365.

66 Yūsuf al-Qaraḍīī, Dawr al-Qiyām wa al-Akhlāq fi al-Iqtisad al-Islami (Qaherah: Maktabah Wahbah, 1995), 237.

67 Maksud ayat 29 surah al-Isra': "Dan janganlah engkau jadikan tanganmu terbelenggu dilehermu, dan janganlah pula engkau menghulurkannya dengan sehabis-habisnya, kerana akibatnya akan tinggallah engkau dengan keadaan yang tercela serta kering keputusan".

68 'Izz al-Dīn bin Zaghibah, Maqāsid al-Sharī'ah al-Khașṣah bi al-Taṣarrufāt al-Māliyah (Amman: Dār al-Nafā' is, 2010), 151.

69 'Izz al-Dīn, Maqāsid al-Sharī'ah al-Khașșah, 151.

70 Maksud ayat 2 surah al-Mā'idah: "Dan tolong menolonglah kamu dalam (mengerjakan) kebaikan dan taqwa, dan janganlah kamu tolong menolong dalam berbuat dosa dan permusuhan." 
metod untuk membantu mereka yang kurang berkemampuan oleh golongan yang berkelebihan harta.

Empat konsep yang ditonjolkan oleh Rasulullah SAW dalam perbelanjaan perkahwinan sewajarnya dijadikan panduan dan seterusnya diaplikasi oleh individu muslim yang akan mendirikan rumah tangga. Biar pun ia hasil daripada penelitian terhadap perbelanjaan mas kahwin dan walimat al-'urs baginda sahaja, namun ia amat relevan untuk digunapakai dalam segala elemen perbelanjaan perkahwinan yang lain. Realitinya, corak perbelanjaan perkahwinan masa kini bukan hanya tertumpu kepada elemen mas kahwin dan walimat al-'urs sahaja, malah terdapat pelbagai elemen perbelanjaan lain yang berasaskan adat, budaya dan trend masyarakat setempat seperti elemen barang hantaran bermula dari proses merisik, bertunang sehingga ke majlis perkahwinan, duit hantaran, pelbagai persiapan untuk majlis perkahwinan dan sebagainya. Perbelanjaan-perbelanjaan untuk tujuan tersebut adalah tidak salah selagi mana perkara-perkara yang dilakukan itu tidak menyanggahi hukum syarak. Walau bagaimana pun, perbelanjaannya haruslah memenuhi konsep yang telah dibincangkan di atas. Perbelanjaan berasaskan konsep tersebut bukan sahaja memenuhi kehendak syarak, malah dapat membantu seseorang individu merancang dan menguruskan perbelanjaan perkahwinannya secara berhemah.

Dalam menguruskan perbelanjaan perkahwinan, individu sewajarnya memastikan apa yang dibelanjakan adalah untuk sesuatu yang mendatangkan manfaat. Elemen-elemen yang tidak mendatangkan manfaat seperti adat hantaran berbentuk sirih junjung dan upah bayaran bagi hiburan yang mempunyai unsur maksiat perlu dielakkan. Individu juga perlu mengukur tahap kemampuan masing-masing sebelum membuat keputusan untuk memperuntukkan kos perbelanjaan bagi perkahwinan. Budaya sambutan perkahwinan bagi golongan berada tidak sewajarnya dijadikan ikutan. Ini kerana sekiranya apa yang dibelanjakan tidak seimbang dengan harta yang dimiliki, ia boleh membawa kepada budaya berhutang sebelum dan seawal usia perkahwinan. Bagi golongan berada yang mengadakan sambutan perkahwinan secara besar-besaran dengan melibatkan perbelanjaan yang tinggi, meski pun mereka berkemampuan, namun perbelanjaan demikian sewajarnya tidak disertai dengan niat yang negatif seperti untuk 
tujuan menunjuk-nunjuk atau berkelakuan sombong, kerana ia adalah makruh di sisi Islam. ${ }^{71}$ Selain itu, pembaziran yang biasa berlaku dalam amalan perbelanjaan perkahwinan masyarakat sekarang perlu dielakkan dengan mengambil sikap sederhana dalam menguruskan segala bentuk elemen perbelanjaan. Bagi elemen kad kahwin sebagai contoh, peruntukan perbelanjaan untuknya perlulah sepadan dengan tujuan perbelanjaan bagi elemen tersebut. Peruntukan yang terlalu tinggi bagi kos untuk sekeping kad boleh membawa kepada unsur pembaziran kerana pada kebiasaannya ia tidak akan digunakan lagi setelah majlis selesai. Bagi meringankan perbelanjaan perkahwinan, masyarakat setempat seharusnya mengamalkan kembali cara sambutan perkahwinan masyarakat Melayu terdahulu. Penyediaan hidangan secara 'gulai kawah' adalah satu cara bagi membantu keluarga pasangan untuk meringankan bebanan perbelanjaan. Kesedaran masyarakat setempat dalam perkara ini amatlah penting bagi mewujudkan kembali konsep bekerjasama dalam menguruskan perbelanjaan perkahwinan.

\section{Penutup}

Konsep perbelanjaan perkahwinan mengikut sunnah Rasulullah SAW adalah ideal untuk dijadikan panduan oleh mereka yang bakal mendirikan rumah tangga. Penghayatan terhadap konsep ini memberi peluang kepada mereka untuk menguruskan perbelanjaan perkahwinan dengan lebih teratur dan terancang. Selain individu yang ingin berkahwin, konsep perbelanjaan perkahwinan yang dibincangkan perlu diketengahkan kepada ahli keluarga pasangan khususnya ibu bapa dan juga pihak jabatan serta institusi yang terlibat secara langsung dengan urusan perkahwinan masyarakat. Ibu bapa merupakan antara orang utama yang terlibat dalam menguruskan hal ehwal sambutan perkahwinan pasangan. Mereka sewajarnya diberi kefahaman tentang konsep ini agar ia mampu diterapkan dalam pengurusan perbelanjaan perkahwinan anakanak mereka. Manakala jabatan dan institusi kerajaan yang berkenaan pula perlu mendedahkan konsep perbelanjaan perkahwinan Rasulullah SAW kepada bakal-bakal pasangan yang akan berhadapan dengan perbelanjaan perkahwinan. Pendedahan

71 'Ala' al-Dīn Abū al-Ḥasan al-Ba'lī, Al-Ikhtiyāāāt al-Fiqhiyyah min Fatāwā Shaykh al-Islām Ibn Taymiyyah (t.tp.: Dār al-Fikr, t.t.), 227. 
dan seterusnya penerapan konsep ini diharapkan dapat membantu masyarakat dalam usaha memudahkan urusan perkahwinan dan mengelakkan daripada berleluasanya budaya berhutang dan kahwin di lewat usia disebabkan bebanan perbelanjaan perkahwinan.

\section{Bibliografi}

Ābādī, Abū al-Ṭayyīb Muḥammad Shams al-Haqq al-'Aẓ̄im. 'Awn al-Ma 'būd Sharh Sunan Abī Dāwūd, ed. 'Abd al-Raḥmān Muhammad 'Uthmān. T.tp.: al-Maktabah al-Salafiyyah, 1979.

Al-'Asqalānī, bin 'Alī bin Ḥajr. Fath al-Bārī bi al-Sharḥ Șaḥịh alBukhārī. Kaherah: Maktabah al-Mișr, 2001.

Al-Ba 'lī, 'Ala' al-Dīn Abū al-Ḥasan. Al-Ikhtiyārāt al-Fiqhiyyah min Fatāwā Shaykh al-Islām Ibn Taymiyyah. T.tp.: Dār al-Fikr, t.t.

Al-Bukhārī, Abū 'Abd Allāh Muhammad bin Ismā’̄il. Șaḥịh alBukhārī, dalam Șāliḥ bin 'Abd al-'Azīz al-Shaykh, Mawsū'at alHadīth al-Sharīf al-Kutub al-Sittah. Riyādh: Dār al-Salām, 2000.

Al-Dahlawī, Aḥmad 'Abd al-Rahīm. Hujjat Allāh al-Balighah. Kaherah: Dār al-Jayl, 2005.

Al-Dusuqī, Shams al-Dīn Muhammad. Hāshiyah al-Dusuqī 'alā al-Sharh al-Kabīr li Dirdir. T.tp.: 'Isā al-Bābī al-Halabī, t.t.

Al-Farghalī, 'Abd al-Hafiz Hamzah al-Nashratī dan Musțafā, 'Abd al-Hamīd. Sìrah $\overline{A l}$ Bayt al-Nabì . T.tp.: al-Maktabah alQayyimah, t.t.

Al-Kasan̄̄, 'Ala' al-Dīn Abī Bakr bin Mas'ūd. Badā' '̄' al-Ṣana '̄̄' fì Tartīb al-Sharā 'ì. Beirut: Dār Ihyā' al-Turath al-'Arab̄̄, 2000.

Al-Qaraḍawī, Yūsuf. Dawr al-Qiyām wa al-Akhlāq fi al-Iqtisad al-Islāmī. Kaherah: Maktabah Wahbah, 1995.

Al-Mawardī, Abū al-Ḥasan 'Alī bin Muḥammad bin Habīb. AlHawī al-Kabīr fì Fiqh Madhhab al-Imām al-Shāfi 'ì. Beirut: Dār al-Kutub al-'Ilmiyyah, 1999.

Al-Nawāwī, Abū Zakariyyā Yahyāa bin Sharf. Șāḥ̄h Muslim bi Sharh al-Nawāwī̄. Kaherah: Dār al-Taqwā, t.t.

Al-Qurțubī, Abū 'Abd Allāh Muḥammad. Al-Jāmi' li Ahkēm alQur'an, ed. Muhammad Ibrāhīm al-Hafnawī dan Maḥmūd Ḥāmid 'Uthmān. Kaherah: Dār al-Haadīth, 2002.

Al-Shāfi'’̄, Muḥammad bin Idrīs. Al-Umm. Mansoura: Dār alWafā', 2001. 
Al-Sibbagh, Rafif 'Abd al-'Azīz. Hafl al-Zifaf fì al-Fiqh al-Islāmī Dawābituhu wa Ahkamuh. Tesis Sarjana, Universiti Damsyik, Syria, 2004.

Al-Sharbinī, Shams al-Dīn Muḥammad bin Muhammad al-Khațib. Mughnī al-Muhtāj ilā Ma 'rīfah Ma 'ānī Alfāz al-Minhājo. Beirut: Dār al-Kutub al-'Ilmiyyah, 1994.

Al-Ṭabarī, Abū Ja'far Muhammad bin Jarīr. Tārīkh al-Ṭabarī alMa 'rūf bi Tārīkh al-Umam wa al-Mulūk. Beirut: Mu'assasah alA'lāmī, 1983.

Al-Ṭabrān̄̄, Ab̄̄ al-Qāsim Sulaymān bin Aḥmad. Al-Mu 'jam alKabīr. Beirut: Mu'assasah al-Rayyān, 2010.

Al-Zabīdī, Muḥammad Murtaḍā. Tāj al-'Arus min Jawāhir alQāmūs. T.tp.: Matba'ah al-Khayriyyah, t.t.

Diyā' al-Dīn, Muḥammad al-Rāzī Fakhr al-Dīn bin. Tafsīr alFakhr al-Rāzì. Beirut: Dār al-Fikr, 1985.

Fatimah Abdullah. "Dari Halaman Rumah ke Dewan Merak Kayangan", SARI Jurnal Alam dan Tamadun Melayu 27, no.1 (Jun-Disember 2009), 101.

Haslina Hassan dan Ann Wan Seng, Wanita dan Perkahwinan. Kuala Lumpur: Dewan Bahasa dan Pustaka, 1995.

Ibn Mājah, Abū 'Abd Allāh Muḥammad bin Yazīd al-Rab'i. "Sunan Ibn Majah", dalam al-Shaykh, Mawsü'at al-Hadith alSharif: al-Kutub al-Sittah, 2591.

Ibn Qudāmah. Al-Mughnī, ed. 'Abd Allāh bin 'Abd al-Muhșin alTurk dan 'Abd al-Fattāḥ Muhammad al-Halw. Riyadh: Dār 'Alam al-Kutub, 1986.

Jabatan Perangkaan Malaysia, dicapai 13 Mac 2013, http://www.statistics.gov.my/portal/download_Labour/files?BP TMS/PST-Siri6.pdf.

Kementerian Pembangunan Wanita, Keluarga dan Masyarakat, dicapai 13 Mac 2013, http://www.kpwkm.gov.my/documents /10156/95f9e1b3-24bb-4cce-af4b-da9bf8317f2e.

Laporan Penyiasatan Perbelanjaan Isi Rumah, laman sesawang Portal Rasmi Jabatan Perangkaan Malaysia, dicapai pada 19 Januari 2015, http://www.statistics.gov.my/portal/download _household/files/Expenditure/Laporan_PIR_Report_on_HES_2 009-10.pdf. 
Monzer Kahf. The Islamic Economy, terj. Ismail Salleh dan Mansor Jusoh. Kuala Lumpur: Pertubuhan Kebajikan Islam Malaysia, 1982.

Muḥammad, 'Alī Jum'ah. al-Makāȳill wa al-Mawāzīn alShar'iyyah. Kaherah: al-Quds, 2001.

Nāṣiḥ Ulwan, 'Abd Allāh. Adāb al-Khițbah wa al-Zifaf wa Huquq al-Zawjayn. Kaherah: Dār al-Salām, 1983.

Raihanah Azahari, Khairun Najmi Saripudin dan Raihana Abd Wahab. "Hubungan di antara Faktor Demografi dengan Penentuan Kadar Hantaran: Kajian di Perlis, Kedah, PulauPinang dan Perak", Jurnal Fiqh 6 (2009), 123.

Persatuan Pengguna Pulau Pinang. Anda dan Wang Anda: Bagaimana Menyimpan \& Berbelanja dengan Bijak. PulauPinang: Persatuan Pengguna Pulau Pinang, 1987.

"Pengantin Dibelenggu Hutang", Laman AKPK, 11 Disember 2012, dicapai 10 Mac 2013, http://www.akpk.org.my/happenings/news/press-release/id/486 /pengantin-dibelenggu-hutang.

Saqr, 'Atiyyah. Mawsū'ah al-Usrah Taht Ri'ayat al-Islām. Kaherah: Maktabah Wahbah, 2003.

Surtahman Kastin Hasan. Ekonomi Islam. Bangi: Universiti Kebangsaan Malaysia, 1990.

Surtahman Kastin Hassan dan Sanep Ahmad. Ekonomi Islam: Dasar dan Amalan. Kuala Lumpur: Dewan Bahasa dan Pustaka, 2010.

Syh Noorul Madihah Syed Husin, Raihanah Azahari dan Asmak Ab. Rahman. "Konsep al-Taysir dalam Perbelanjaan Perkahwinan Islam", Jurnal Syariah 22, no.3 (September Disember 2014): 337.

Zaghibah, 'Izz al-Dīn bin. Maqāsid al-Sharī'ah al-Khașșah bi alTașarrufāt al-Māliyah. Amman: Dār al-Nafā'is, 2010. 